\title{
EFFECT OF IRRIGATION, POTASSIUM APPLICATION AND DISTANCE, FROM DRAIN LINE ON TUBER YIELD OF POTATOES (Solanum tuberosum L.) CROP IN MIDDLE DELTA \\ El- Araby, A. A. ${ }^{1}$ and Naglaa H. H. Hessin ${ }^{2}$ \\ 1-Soils, Water and Environment Research Institute, A.R.C., Giza, Egypt \\ 2-Hort.Res.Ins.,ARC., Giza, Egypt
}

\begin{abstract}
Two field experiments were carried out at Kafer El-Zayat,. El-Gharbia Governorate, Middle Delta and allocated at 30-50' N Latitude, 30-49'E Longitude . during the two successive seasons of 2009/2010 and 2010/2011. The field is provided by tile drain network spaced at $20 \mathrm{~m}$. with $1.2 \mathrm{~m}$. depth, in order to study the effect of distances from drain line, potassium application and irrigation scheduling on yield of potatoes. Experiments were conducted in a split- split- plot design. The study was concerned with the use of different rates of potassium fertilization $(0,72,96$ and 120 $\mathrm{kg} \mathrm{K}_{2} \mathrm{O} / \mathrm{fed}$.) under different irrigation scheduling (40,60 and $80 \%$ of available water) Results showed that:

Decreasing distance from drain line $\mathrm{L} / 2$ to $\mathrm{L} / 4$ to $\mathrm{L} / 8$ gave significant increase in potatoes yield. The study concerned the use of different rates of potassium fertilization $\left(0,72,96\right.$ and $120 \mathrm{~kg} \mathrm{~K} \mathrm{~K}_{2} \mathrm{O} / \mathrm{fed}$.), under different irrigation scheduling (40,60 and $80 \%$ of available water)on potatoes crop in clay soil. Generally, in most cases, the treatment of the medium and highest soil moisture level (60 and $80 \%$ of available water) gave the highest significant values, potatoes tuber, as well as, consumptive use. While the lowest one were recorded when the lowest soil moisture level (40\% of available water) was applied.. Generally, all $\mathrm{k}$ rates gave the highest significant values for all parameters under study. The second level of potassium $96 \mathrm{~kg} \mathrm{~K}_{2} \mathrm{O} /$ fed. achieved the highest significant values of tuber yield,. Whereas, the high values of water productivity and consumptive use were obtained when 120 $\mathrm{kg} \mathrm{K} \mathrm{K}_{2} \mathrm{O} / \mathrm{fed}$. and $40 \%$ available water were applied. In most cases, were high levels of potassium under $80 \%$ of available water gave the highest significant values for all parameters under study in both seasons.
\end{abstract}

Keywords: Drain line , potatoes, yield, irrigation scheduling and water productivity.

\section{INTRODUCTION}

Production of potatoes (Solanum tuberosum L.) takes a very important place in world agriculture, with production potential of about 327 million tons harvested and 18.6 million ha planted area (FAO, 2004). Potatoes are considered one of the most important vegetable crops grown in Egypt, as well as, in the whole world. It occupies a great figure in local consumption and export. The performance of any crop depends not only on its genetic characteristics but also on the surrounding environmental conditions, particularly, methods of irrigation and water supply. Therefore, growers have to adopt modern techniques of cultivation. Potatoes is one of the world's major food crops where the dry matter production/ha is more than other major cereal crops (Burton, 1984). Developing countries produce 93 million tons 
representing one-third of the world's production (FAO, 1988). The consumer's requirements for fresh potatoes are often associated with aesthetic and internal qualities including the appearance of the tubers, freedom from defects and contaminants.

Fertilization especially potassium, is considered one of the most important factors affecting the growth and yield of potatoes. Potassium has two roles in the functioning of plant cells. First, it has an irreplaceable part to play in the activation of enzymes which are fundamental to metabolic processes, especially the production of proteins and sugars. Only small amounts of potassium are required for this biochemical function. Second, potassium is the "plant-preferred" ion for maintaining the water content and hence the turgidity (rigidity) of plant cells.. Because of its very importance in turgid maintenance, potassium is essential to obtain maximum leaf extension and stem elongation.

Many researchers recorded an increase of potatoes tubers yield as a result of increasing the levels of potassium (K) fertilization El-Gamal (1985) and Humadi (1986) Such increases in yield of potatoes tubers was either due to the formation of large size tubers or increasing of the number of tubers per plant or both. Potassium also plays a key role in increasing crop yield and improving the quality of produce Tisdale et al (1985).

Few studies on irrigation water requirements of potatoes crop, especially in the newly reclaimed soils, were conducted in Egypt. Increasing number of irrigations, levels of field capacity, irrigation amounts, pan evaporation ratios and/or potential evapotranspiration (ETo) up to the maximum level increased growth parameters; i.e. leaf area, total plant dry matter (Fatthallah and Gawish, (1997).Irrigation frequency is one of the most important factors in trickle irrigation scheduling. Due to the differences in soil moisture and wetting pattern, crop yields may be different when the same quantity of water. ). High frequency irrigation enhanced potato tuber growth and water use efficiency.

The aim of the present work was study the effect of the distance from drain line, irrigation regime and potassium application on growth of potato yield.

\section{MATERIALS AND METHODS}

A field trial was conducted during the two successive growing seasons 2009/2010 and 2010/2011 at Ebiar village in Kafr EL-Zayat, ElGharbia Governorate, Middle Delta. The site represents the circumstances and conditions of Middle Nile Delta region and allocated at 30-50' N Latitude, 30-49'E Longitude .Potatoes tubers of Diamante variety were planted on Dec.7, 2009, as winter plantation (Season 2009/2010), and on Dec. 10,2010 as (season 2010/2011). Harvesting was generally carried out after 115 days from planting. Seed tubers were dipped in a solution of Rhizolex $(1 \mathrm{~g})$ dissolved in 1 liter of water for 5 minutes and dried in shade before planting, which prevents the decay of seed tubers. The soil texture of this experimental 
site is clayey, the rain fall of the region were 100 and $140 \mathrm{~mm}$ in the first and second seasons respectively.

Table (1): Mean of some meteorological data for Kafr EL-Zayat area during the two growing seasons of potatoes crop

\begin{tabular}{|c|c|c|c|c|c|c|c|c|c|c|c|c|c|c|}
\hline & \multicolumn{7}{|c|}{ Season $2009 / 2010$} & \multicolumn{7}{|c|}{ Season $2010 / 2011$} \\
\hline & \multicolumn{2}{|c|}{$\begin{array}{c}\text { Air } \\
\text { Temp.C }\end{array}$} & \multicolumn{2}{|c|}{$\begin{array}{c}\text { Relative } \\
\text { humidity, \% }\end{array}$} & \multirow{2}{*}{ 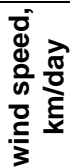 } & \multirow{2}{*}{ 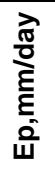 } & \multirow{2}{*}{. } & \multicolumn{2}{|c|}{$\begin{array}{c}\text { Air } \\
\text { Temp. } \mathbf{C}^{\circ}\end{array}$} & \multicolumn{2}{|c|}{$\begin{array}{c}\text { Relative } \\
\text { humidity, } \\
\%\end{array}$} & \multirow{2}{*}{ 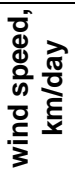 } & \multirow{2}{*}{ 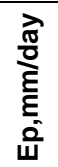 } & \multirow{2}{*}{ 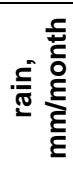 } \\
\hline & ma & min. & m & $\min$ & & & & $\mathbf{m}$ & $\min$ & $\max$ & $\min$ & & & \\
\hline Nov. & 26.0 & 10.5 & 71.1 & 50.0 & 58 & 2.7 & --- & 26.8 & 11.0 & 2.0 & 54.2 & 63 & 2.8 & \\
\hline Dec. & 22.2 & 8.8 & 76.5 & 52.0 & 64.0 & 2.1 & 58 & 22. & 8. & 85.0 & 55.7 & 58.3 & 1.8 & 90.0 \\
\hline Jan. & 21.5 & 7.8 & 83.5 & 55.0 & 53.0 & 1.8 & --- & 20.3 & 5.8 & 84.2 & 54.0 & 42.5 & 1.9 & ------- \\
\hline Feb. & 24.5 & 9.4 & 84.2 & 55.7 & 76.8 & 2.9 & 32 & 23.4 & 7.4 & 87.0 & 54.0 & 64.0 & 2.9 & 22.5 \\
\hline Mar- & 24.3 & 10.0 & 76.3 & 44.0 & 110 & 4.3 & 10 & 21.8 & 6.8 & 86.3 & 49.5 & 77.4 & 3.4 & 14.0 \\
\hline Apr- & 28.2 & 11.0 & 96.0 & 40.7 & 96 & 5.6 & ---- & 26.5 & 10. & 85.0 & 47.7 & 83.7 & 4.9 & ---- \\
\hline May- & 29.6 & 14.4 & 72.6 & 39.5 & 96 & 6.9 & ----- & 29.0 & 13.0 & 76.7 & 38.0 & 102.0 & 5.9 & - \\
\hline
\end{tabular}

* Source: meteorological station at Sakha 31-07' N Latitude, 30-57'E Longitude, N.elevation $6 \mathrm{~m}$.

The experiments were conducted in a split -split -plot design with three replicates .The main plots were distances from drain line, the sub- plots were potassium application and the sub -sub- plots were Irrigation treatments as follow:

Main plots (distances from drain line):

$\mathrm{L} / 2$ :Distances of $1 / 2$ from drain line ,L/4:Distances of $1 / 4$ from drain line, and L/8:Distances of 1/8 from drain line

sub- plots (potassium application):

a- $80 \%$ of available water $\left(I_{1}\right), b-60 \%$ of available water $\left(I_{2}\right)$.

c- $40 \%$ of available water $\left(I_{3}\right)$.

sub -sub- plots (irrigation)

$\mathrm{K}$ fertilizer in the form of potassium sulphate $\left(48 \% \mathrm{~K}_{2} \mathrm{O}\right)$ were four levels i.e., $\mathrm{K}_{0}(0), \mathrm{K}_{1}(72), \mathrm{K}_{2}(96)$ and $\mathrm{K}_{3}(120) \mathrm{kg} \mathrm{K}_{2} \mathrm{O} / \mathrm{fed}$., respectively. The fertilizer was applied before cultivation.

Table (2): Mean values of some soil Physical chemical properties and some water constants of the experimental site before cultivation in the two growing seasons

\begin{tabular}{|c|c|c|c|c|c|c|c|c|c|c|c|c|c|c|c|c|c|c|}
\hline \multirow{2}{*}{$\begin{array}{l}\frac{\overline{0}}{\frac{0}{d}} \\
\frac{\bar{g}}{\bar{c}} \\
\bar{c}\end{array}$} & \multicolumn{3}{|c|}{\begin{tabular}{|c|} 
Particle size \\
distribution $\%$ \\
\end{tabular}} & \multirow{2}{*}{ 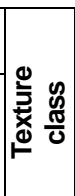 } & \multirow[b]{2}{*}{ ○̊ } & \multirow{2}{*}{$\begin{array}{l}\circ \\
\circ \\
0 \\
3 \\
0 \\
0\end{array}$} & \multirow{2}{*}{ 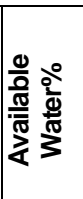 } & \multirow{2}{*}{ 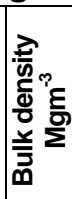 } & \multirow{2}{*}{ 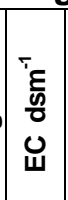 } & & \multicolumn{4}{|c|}{$\begin{array}{c}\text { Soluble cations } \\
\text { MeqL }^{-1}\end{array}$} & \multicolumn{4}{|c|}{\begin{tabular}{|c|}
$\begin{array}{c}\text { Soluble anions } \\
\text { MeqL }^{-1}\end{array}$ \\
\end{tabular}} \\
\hline & 胥 & \pm & $\frac{\mathrm{\pi}}{0}$ & & & & & & & & $\mathrm{Ca}^{2+}$ & $\mathrm{Mg}^{2+}$ & $\mathrm{Na}^{+}$ & $\mathrm{K}^{+}$ & 8 & 'o & $\overline{0}$ & o \\
\hline 15 & .0 & .0 & 6.0 & Clay & 4 & 5.3 & \begin{tabular}{|l|l}
321.7 \\
\end{tabular} & 1.19 & 1.5 & 8.15 & 0.30 & & & & & 0.55 & 0.21 & 0.42 \\
\hline 0 & tis & 0.0 & 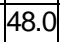 & ay & 3 & 21.8 & \begin{tabular}{|l|l}
317.2 \\
\end{tabular} & 16 & 1.57 & $\overline{0}$ & & & & & & U.UT & 0.54 & \\
\hline )-45 & 26.5 & 26.0 & | & Clay & 38.0 & 21.9 & \begin{tabular}{|l|l}
9 & 16.1
\end{tabular} & 1.30 & 1.65 & 8.00 & 0.34 & & & & & 0.65 & & $0.4 t$ \\
\hline & & & & & & 0.8 & \begin{tabular}{|l|l}
3 & 17.7
\end{tabular} & 20 & 2 & & & & & & & 0.45 & & 1.71 \\
\hline
\end{tabular}




\section{El- Araby, A. A. and Naglaa H. H. Hessin}

Data collection:

Irrigation water applied (Wa):

Submerged flow orifice with fixed dimensions was used to convey and measure the irrigation water applied, according to the following equation (Michael, 1978).

$$
\mathbf{Q}=\mathbf{C A} \sqrt{2 \mathrm{gh}}
$$

Where:

$\mathrm{Q} \quad=$ Discharge through orifice, $\left(\mathrm{cm}^{3} \mathrm{sec}^{-1}\right)$.

C $\quad=$ Coefficient of discharges (0.61).

A = Cross sectional area of orifice, $\mathrm{cm}^{2}$.

$\mathrm{g}=$ Acceleration due to gravity, $\mathrm{cm} / \mathrm{sec}^{2}(980 \mathrm{~cm} / \mathrm{sec})$.

$\mathrm{H}=$ Pressure head, over the orifice center, $\mathrm{cm}$.

Total number of irrigation were events 10,7 and 5 for treatment $I_{1}, I_{2}$ and $I_{3}$, respectively including sowing irrigation.

consumptive use (CU):

Water consumptive use was calculated using the following

equation (Hansen et al., 1979).

$$
\mathrm{Cu}=\sum_{i=1}^{\mathrm{l}=4} \mathrm{D}_{1} \times \mathrm{D}_{\mathrm{b} 1} \times \frac{\mathrm{PW}_{2}-\mathrm{PW}_{1}}{100}
$$

$\mathrm{CU}=$ Water consumptive use $(\mathrm{cm})$ in the effective root zone $(60 \mathrm{~cm})$.

$D_{1} \quad=$ Soil layer depth $(15 \mathrm{~cm}$ each $)$.

$D_{b 1}=$ Soil bulk density, $\left(\mathrm{Mgm}^{-3}\right)$ for the given depth.

$\mathrm{PW}_{1}=$ Soil moisture percentage before irrigation (on mass basis, \%).

$\mathrm{PW}_{1}=$ Soil moisture percentage, 48 hours after irrigation (on mass basis, \%).

I = Number of soil layers each $(15 \mathrm{~cm})$ depth.

Water productivity (WP):

It was calculated according to (Ali et al., 2007).

$W P=G Y / C_{u}$.

Where WP $\left(\mathrm{kg} / \mathrm{m}^{3}\right)$, GY is grain yield $(\mathrm{kg} / \mathrm{fed})$.

and $C_{u}$ total water consumption of the growing season $\left(\mathrm{m}^{3} / \mathrm{fed}\right.$.)

Productivity of irrigation water (PIW)

was calculated as (Ali et al., 2007)

$\mathrm{PIW}=\mathrm{GY} / \mathrm{I}$

Where I is irrigation water applied $\left(\mathrm{m}^{3} / \mathrm{fed}\right.$.).

The obtained data were statistically analyzed according to Gomez and Gomez, (1984).

\section{RESULTS AND DISCUSSION}

\section{Water applied:}

Water applied (WA) to tuber potatoes consists of two items. These are (1) irrigation water (IW) and (2) rainfall (RF), as shown in Table (2). Amount of irrigation water (IW) for $I_{3}$ treatment is the lowest, and the amount for $I_{1}$ treatment was the highest. Total values of applied for $I_{1}, I_{2}$ and $I_{3}$ treatments 
were 2567, 2101, $1787 \mathrm{m3}$ / fed. and 2798, $2488,1938 \mathrm{~m} 3 /$ fed for first and second season respectively. Water applied in the second season more than the first season caused by the difference between the rainfall in these two seasons. Sowing irrigation was the same for all irrigation treatments. The effective rainfalls were $420 \mathrm{~m}^{3}$ and $588 \mathrm{~m}^{3}$ over both growing seasons. It is obvious that amount of irrigation water applied was gradually increased as a result of growing up of a vegetative growth that required higher amounts of irrigation water to meet its water requirements, then it decreased again. These findings may be attributed to growth stages, and the availability of soil water content in the root zone.

Table (3): Number and irrigation intervals as affected by irrigation treatments during the two growing seasons

\begin{tabular}{|c|c|c|c|c|c|c|c|c|c|c|c|c|}
\hline \multirow{2}{*}{ Treatments } & \multicolumn{10}{|c|}{ Season $\mathbf{2 0 0 9 / 2 0 1 0}$} \\
& $\mathbf{1}^{\text {st }}$ & $\mathbf{2}^{\text {nd }}$ & $\mathbf{3}^{\text {rd }}$ & $\mathbf{4}^{\text {th }}$ & $\mathbf{5}^{\text {th }}$ & $\mathbf{6}^{\text {th }}$ & $\mathbf{7}^{\text {th }}$ & $8^{\text {th }}$ & $9^{\text {th }}$ & $10^{\text {th }}$ & Rain fall & Total \\
\hline $\mathbf{I}_{\mathbf{1}}(\mathbf{8 0} \%$ of $\mathbf{A W})$ & 437 & 170 & 180 & 200 & 220 & 240 & 210 & 190 & 180 & 120 & 420 & 2567 \\
\hline $\mathbf{I}_{\mathbf{2}}(\mathbf{6 0} \%$ of AW $)$ & 437 & 200 & 230 & 260 & 200 & 200 & 154 & & & & 420 & 2101 \\
\hline $\mathbf{I}_{\mathbf{3}} \mathbf{( 4 0 \%}$ of $\left.\mathbf{W}\right)$ & 437 & 200 & 200 & 280 & 250 & & & & & & 420 & 1787 \\
\hline & \multicolumn{10}{|c|}{ Season $\mathbf{2 0 1 0 / 2 0 1 1}$} \\
\hline $\mathbf{I}_{\mathbf{1}}(\mathbf{8 0} \%$ of $\mathbf{A W})$ & 480 & 180 & 190 & 200 & 210 & 230 & 220 & 200 & 170 & 130 & 588 & 2798 \\
\hline $\mathbf{I}_{\mathbf{2}}(\mathbf{6 0} \%$ of AW $)$ & 480 & 200 & 220 & 310 & 270 & 220 & 200 & & & & 588 & 2488 \\
\hline $\mathbf{I}_{\mathbf{3}} \mathbf{( 4 0 \%}$ of $\left.\mathbf{W}\right)$ & 480 & 190 & 200 & 200 & 280 & & & & & & 588 & 1938 \\
\hline
\end{tabular}

\section{Consumptive use $(\mathrm{Cu})$ :}

Tabulated data in Table (7) revealed that $(\mathrm{Cu})$ increased as the irrigation application increased. potatoes plants of irrigation treatment $I_{1}$ has the highest value of water consumption followed by potatoes plants in the treatments $\left(\mathrm{I}_{2}\right)$ and $\left(\mathrm{I}_{3}\right)$, respectively. Mean values of seasonal water consumptive use were $2120.0,1980.0$ and $1200.9 \mathrm{~m}^{3}$ /season, for the treatments of $80,, 60$ and $40 \%$ of available water respectively. The most probably explanation for these results is that more available soil moisture was resulted from more irrigation times, giving chance for luxury consumption of water, which ultimately resulted in enhancing transpiration from potatoes plants, in addition to high water evaporation from the soil. obtained data in table ( 6 ) revealed that the treatment of $120 \mathrm{~K}_{2} \mathrm{O} \mathrm{kg} / \mathrm{fed}$. with $80 \%$ of available water gave a highly significant in consumptive use in both seasons. The lowest value was obtained with control (without addition of $\mathrm{K}$ fertilizers) under $40 \%$ of available water .

\section{Effect of distances from drain line on potatoes tuber yield :}

Data in table ( 5 ) showed that decreasing distance from drain line $L / 2$ to $L / 4$ to $L / 8$ resulted in significant increase of the potatoes tuber yield (ton/fed). Values of potatoes tuber yield near the drain were 12.412, 11.777 and 11.253 for L/8, L/4 and L/2 respectively as a mean values for first and second seasons. This was due to the effect of drainage on conditioning water-air relationship in the root zone, and its effect on mobility of nutrients to the plant roots, which caused more vegetative growth and subsequently produced, higher yield. These results are in agreement with those obtained by Ramadan et al ( 2006) and Gendy et al (2009). 


\section{Effect of irrigation regime on potatoes tuber yield :}

Data in Table (4) showed that total yield /fed significantly decreased as water stress was increased. The highest potato yield was obtained by irrigation with $80 \%$ of available water $(16550 \mathrm{~kg} / \mathrm{fed})$ as mean of the two seasons. It is obvious that frequent irrigation (short time between irrigations) produced maximum values of total yield of potato at the two studied seasons. On the contrary, minimum of total yield was 7.500 ton/fed in the two studied seasons were obtained when potatoes irrigation was at $40 \%$ of available soil moisture.. It can be terminated that, total yield of tubers increased with increasing irrigation frequency (irrigation at $80 \%$ available soil moisture). These results are similar to those findings by Balanger et al. (2000)and Youssef et al (2007). As a general view, data of interacted factors under such investigation illustrated in Table (4) indicated that all treatments of $\mathrm{K}$ levels with $80 \%$ of available water gave the highest significant value of tuber yield, while, the lowest value was obtained when the control treatment (without addition of $\mathrm{K}$ fertilizers) or/and $\mathrm{K}_{1}$ under $40 \%$ of available water was practiced in both seasons.

Table (4): Effect of distances from drain line,potassium application and irrigation treatment on tuber potatoes yield (ton/fed), in combined analysis of the two growing seasons.

\begin{tabular}{|c|c|c|c|c|c|}
\hline & & $\begin{array}{c}\mathrm{l}_{1} \\
(40 \% \text { of } \mathrm{AW})\end{array}$ & $\begin{array}{c}\mathrm{I}_{2} \\
(60 \% \text { of } \mathrm{AW})\end{array}$ & $\begin{array}{c}I_{3} \\
(80 \% \text { of } A W)\end{array}$ & $\begin{array}{c}\mathrm{K} \\
\text { mean }\end{array}$ \\
\hline \multirow[t]{4}{*}{$L / 8$} & $\mathrm{~K}_{0}$ & $8.727 \quad c$ & $9.183 \mathrm{C}$ & $9.400 \mathrm{~d}$ & 9.103 \\
\hline & $\mathrm{K}_{72}$ & $11.310 \mathrm{~b}$ & $12.820 \mathrm{~b}$ & $13.693 \mathrm{c}$ & 12.608 \\
\hline & $\mathrm{K}_{96}$ & $12.617 \mathrm{a}$ & $13.397 \mathrm{a}$ & $15.100 \mathrm{~b}$ & 13.704 \\
\hline & $\mathrm{K}_{120}$ & $12.967 \mathrm{a}$ & $13.180 \mathrm{ab}$ & $16.550 \mathrm{a}$ & 14.232 \\
\hline \multirow[t]{4}{*}{$L / 4$} & $\mathrm{~K}_{0}$ & $8.127 \quad c$ & $9.043 \quad c$ & 9.157 & 8.776 \\
\hline & $\mathrm{K}_{72}$ & $10.700 \quad b$ & $12.167 \quad b$ & $12.487 \quad b$ & 11.784 \\
\hline & $\mathrm{K}_{96}$ & $12.093 \mathrm{a}$ & $12.760 \quad \mathrm{a}$ & $14.823 \quad a$ & 13.226 \\
\hline & $\mathrm{K}_{120}$ & $12.167 \quad \mathrm{a}$ & $12.700 \quad \mathrm{a}$ & $15.100 \quad \mathrm{a}$ & 13.322 \\
\hline \multirow[t]{4}{*}{$L / 2$} & $\mathrm{~K}_{0}$ & $7.500 \quad c$ & $8.933 \mathrm{c}$ & 9.000 & 8.478 \\
\hline & $\mathrm{K}_{72}$ & $10.053 \mathrm{~b}$ & $11.920 \mathrm{~b}$ & 12.000 & 11.324 \\
\hline & $\mathrm{K}_{96}$ & $11.267 \quad \mathrm{a}$ & $12.100 \mathrm{~b}$ & 13.833 & 12.400 \\
\hline & $K_{120}$ & $11.600 \quad \mathrm{a}$ & $12.800 \quad \mathrm{a}$ & 14.027 & 12.809 \\
\hline I Mean & & 10.760 & 11.750 & 12.913 & 11.814 \\
\hline
\end{tabular}

In column under each $\mathrm{L}$, means followed by a common letter are not significantly different at the $5 \%$ level by DMRT.

$\begin{array}{lccc}\text { Comparison } & \text { S.E.D } & \text { LSD (5\%) } & \text { LSD (1\%) } \\ \text { 2- I means at each } L^{*} K & 0.191 & 0.385 & 0.513 \\ \text { 2- k means at each } L^{*} \text { I } & 0.184 & 0.375 & 0.504\end{array}$

Interaction between distance from drain line and irrigation regime on tuber yield:

Data in table (5) show that, tuber yield was significantly decreased with increasing the distance from drain line in both studied season

Available data in Table (5) reveal obviously that the yield of tuber were affected significantly by irrigation treatments, the treatment of $80 \%$ of 
available water gave a highest significant values, while, the lowest one were obtained when $40 \%$ of available water was applied in both seasons.

Table (5): Interaction between distance from drain line and irrigation treatment on tuber potatoes yield ton/fed

\begin{tabular}{|l|c|c|c|c|}
\hline & $\mathbf{L} / \mathbf{8}$ & $\mathbf{L} / \mathbf{4}$ & $\mathbf{L} / \mathbf{2}$ & Mean \\
\hline $40 \%$ of AW & 11.405 & 10.772 & 10.105 & $\mathbf{1 0 . 7 6 1}$ \\
\hline $60 \%$ of AW & 12.145 & 11.668 & 11.438 & $\mathbf{1 1 . 7 5 0}$ \\
\hline $80 \%$ of AW & 13.686 & 12.892 & 12.215 & $\mathbf{1 2 . 9 3 1}$ \\
\hline Mean & $\mathbf{1 2 . 4 1 2}$ & $\mathbf{1 1 . 7 7 7}$ & $\mathbf{1 1 . 2 5 3}$ & $\mathbf{1 1 . 8 1 4}$ \\
\hline
\end{tabular}

\section{Effect of K-fertilization on potatoes tuber:}

Examining the effect of potassium levels on potatoes yield tuber ton/fed., the highest significant values were obtained when plants treated with $120 \mathrm{~K}_{2} \mathrm{O} \mathrm{kg} / \mathrm{fed}$. as compared to other treatments of $\mathrm{K}$ fertilizers, while, the lowest one were recorded with control (without addition of $K$ fertilizers) in both seasons. These results are similar to those found by Balanger et al. (2000)and Youssef et al (2007).

Interaction between K-fertilization and irrigation regime on tuber yield:

Data presented in Table (6) showed that treatments of $80 \%$ of available water gave the highest significant values of potatoes yield tuber $\mathrm{kg} / \mathrm{fed}$., while, the lowest value was recorded with the treatment of $40 \%$ of available water in both seasons. Bosnjak et al (1997) found that tubers yield were highest in the $75-80 \%$ available water. This was equivalent to a water requirement of $460-480 \mathrm{~mm}$ / season. Ghosh et al (2000)found that tuber yield decreased with decreasing soil moisture with the greatest reduction at $45 \%$ AW.

With respect to the interacted factors under the current study, data tabulated in Table (6) revealed that high level of $\mathrm{K}$ fertilizer $\left(120 \mathrm{~K}_{2} \mathrm{O} \mathrm{kg} / \mathrm{fed}\right.$.) gave the highest significant values of potato yield tuber ton/fed. under $80 \%$ of available water, whereas, the lowest value was recorded with control (without addition of $\mathrm{K}$ fertilizers) with $40 \%$ of available water in both seasons. Alternatively, $\mathrm{K}_{3}$ and $\mathrm{K}_{2}$ had similar effect on potato yield tuber ( ton/fed.) under $80 \%$ of available water in 2 nd season only.

Table (6): Interaction between K-fertilization and irrigation regime on tuber yield (ton/fed.):

\begin{tabular}{|l|c|c|c|c|}
\hline & $\mathbf{4 0} \%$ of AW & $\mathbf{6 0} \%$ of AW & $\mathbf{8 0} \%$ of AW & Mean \\
\hline $\mathrm{K}_{1}\left(0 \mathrm{~K}_{2} \mathrm{O}\right)$ & 8.118 & 9.053 & 9.186 & 8.478 \\
\hline $\mathrm{K}_{2}\left(72 \mathrm{k}_{2} \mathrm{O}\right)$ & 10.688 & 12.302 & 12.727 & 11.324 \\
\hline $\mathrm{K}_{3}\left(96 \mathrm{k}_{2} \mathrm{O}\right)$ & 11.992 & 12.752 & 14.586 & 12.400 \\
\hline $\mathrm{K}_{4}\left(120 \mathrm{k}_{2} \mathrm{O}\right)$ & 12.244 & 12.893 & 15.226 & 12.809 \\
\hline Mean & 10.761 & 11.750 & 12.931 & 11.814 \\
\hline
\end{tabular}

Water productivity (WP):

Data in table (7) showed that In most cases, that water productivity was affected significantly when potassium was added by any rates with any soil moisture levels in the current study as compared to control (without addition 
of $\mathrm{K}$ fertilizers) in the first season. In 2 nd one the $\mathrm{K}_{2}$ and $\mathrm{K}_{3}$ with $80 \%$ of available water had a similar significant effects, while, the lowest yield was recorded when control (without addition of $\mathrm{K}$ fertilizers) under $80 \%$ of available water was added. On the other hand, water productivity wasn't affected significantly by irrigation treatments in both seasons. Similar results were recorded by; Ali (1993)

Table (7): Potatoes yield (kg/fed), consumptive use $\left(\mathrm{m}^{3}\right)$, Water applied $\left(\mathrm{m}^{3}\right)$, Water productivity $\mathrm{Kg} / \mathrm{m}$ (WP) and Productivity of irrigation water $\mathrm{Kg} / \mathrm{m}^{3}$ (PIW) in the combined analysis over both seasons.

\begin{tabular}{|c|c|c|c|c|c|c|c|}
\hline \begin{tabular}{|l|} 
Distance \\
from drain
\end{tabular} & $\begin{array}{l}\text { Potassium } \\
\text { applied }\end{array}$ & $\begin{array}{l}\text { Irrigation } \\
\text { treatment }\end{array}$ & $\begin{array}{c}\text { Yield } \\
\mathrm{kg} / \mathrm{fed} .\end{array}$ & $\begin{array}{c}\mathrm{C}_{\mathrm{u}} \\
\left(\mathrm{m}^{3} / \mathrm{fed}\right)\end{array}$ & $\begin{array}{c}\begin{array}{c}W a \\
\left(\mathrm{~m}^{3} / \mathrm{fed}\right)\end{array} \\
\end{array}$ & $\begin{array}{c}\text { WP } \\
\left(\mathrm{kg} / \mathrm{m}^{3}\right)\end{array}$ & $\begin{array}{c}\mathrm{PIW} \\
\left(\mathrm{kg} / \mathrm{m}^{3}\right)\end{array}$ \\
\hline \multirow{12}{*}{ L/2 } & \multirow{3}{*}{$K_{0}$} & $80 \%$ AW & 9000 & 2120.0 & 2682.5 & 4.245 & 3.355 \\
\hline & & $60 \%$ AW & 8933 & 1980.0 & 2294.5 & 4.512 & 3.893 \\
\hline & & $40 \%$ AW & 7500 & 1200.9 & 1862.5 & 6.245 & 4.026 \\
\hline & \multirow{3}{*}{$K_{72}$} & $80 \%$ AW & 12000 & 2120.0 & 2682.5 & 5.660 & 4.473 \\
\hline & & $60 \%$ AW & 11920 & 1980.0 & 2294.5 & 6.020 & 5.195 \\
\hline & & $40 \%$ AW & 10053 & 1200.9 & 1862.5 & 8.371 & 5.397 \\
\hline & \multirow{3}{*}{$\mathrm{K}_{96}$} & $80 \%$ AW & 13833 & 2120.0 & 2682.5 & 6.525 & 5.156 \\
\hline & & $60 \%$ AW & 12100 & 1980.0 & 2294.5 & 6.111 & 5.273 \\
\hline & & $40 \%$ AW & 11267 & 1200.9 & 1862.5 & 9.382 & 6.049 \\
\hline & \multirow{3}{*}{$K_{120}$} & $80 \%$ AW & 14027 & 2120.0 & 2682.5 & 6.617 & 5.229 \\
\hline & & $60 \%$ AW & 12800 & 1980.0 & 2294.5 & 6.465 & 5.578 \\
\hline & & $40 \%$ AW & 11600 & 1200.9 & 1862.5 & 9.659 & 6.228 \\
\hline \multirow{12}{*}{$\mathrm{L} / 4$} & \multirow{3}{*}{$K_{0}$} & $80 \%$ AW & 9157 & 2120.0 & 2682.5 & 4.319 & 3.413 \\
\hline & & $60 \%$ AW & 9043 & 1980.0 & 2294.5 & 4.567 & 3.941 \\
\hline & & $40 \%$ AW & 8127 & 1200.9 & 1862.5 & 6.767 & 4.363 \\
\hline & \multirow{3}{*}{$\mathrm{K}_{72}$} & $80 \%$ AW & 12487 & 2120.0 & 2682.5 & 5.890 & 4.654 \\
\hline & & $60 \%$ AW & 12167 & 1980.0 & 2294.5 & 6.145 & 5.302 \\
\hline & & $40 \%$ AW & 10700 & 1200.9 & 1862.5 & 8.910 & 5.744 \\
\hline & \multirow{3}{*}{$K_{96}$} & $80 \%$ AW & 14823 & 2120.0 & 2682.5 & 6.992 & 5.525 \\
\hline & & $60 \%$ AW & 12760 & 1980.0 & 2294.5 & 6.444 & 5.561 \\
\hline & & $40 \%$ AW & 12093 & 1200.9 & 1862.5 & 10.070 & 6.492 \\
\hline & \multirow{3}{*}{$K_{120}$} & $80 \%$ AW & 15100 & 2120.0 & 2682.5 & 7.123 & 5.629 \\
\hline & & $60 \%$ AW & 12700 & 1980.0 & 2294.5 & 6.414 & 5.534 \\
\hline & & $40 \%$ AW & 12167 & 1200.9 & 1862.5 & 10.132 & 6.532 \\
\hline \multirow{12}{*}{$\mathrm{L} / 8$} & \multirow{3}{*}{$K_{0}$} & $80 \%$ AW & 9400 & 2120.0 & 2682.5 & 4.434 & 3.504 \\
\hline & & $60 \%$ AW & 9183 & 1980.0 & 2294.5 & 4.638 & 4.002 \\
\hline & & $40 \%$ AW & 8727 & 1200.9 & 1862.5 & 7.267 & 4.685 \\
\hline & \multirow{3}{*}{$\mathrm{K}_{72}$} & $80 \%$ AW & 12000 & 2120.0 & 2682.5 & 5.660 & 4.473 \\
\hline & & $60 \%$ AW & 11920 & 1980.0 & 2294.5 & 6.020 & 5.195 \\
\hline & & $40 \%$ AW & 10053 & 1200.9 & 1862.5 & 8.371 & 5.397 \\
\hline & \multirow{3}{*}{$K_{96}$} & $80 \%$ AW & 15100 & 2120.0 & 2682.5 & 7.123 & 5.629 \\
\hline & & $60 \%$ AW & 13397 & 1980.0 & 2294.5 & 6.766 & 5.838 \\
\hline & & $40 \%$ AW & 12617 & 1200.9 & 1862.5 & 10.506 & 6.774 \\
\hline & \multirow{3}{*}{$K_{120}$} & $80 \%$ AW & 16550 & 2120.0 & 2682.5 & 7.807 & 6.169 \\
\hline & & $60 \%$ AW & 13180 & 1980.0 & 2294.5 & 6.657 & 5.744 \\
\hline & & $40 \%$ AW & 12967 & 1200.9 & 1862.5 & 10.798 & 6.962 \\
\hline
\end{tabular}




\section{Productivity of irrigation water (PIW):}

Results in Table (7) cleared that with increasing the irrigation intervals, PIW was increased. Highest average values of PIW $6.962 \mathrm{~kg} / \mathrm{m}^{3}$ for tuber yield, , were obtained under treatment $40 \%$ of $\mathrm{AW}\left(\mathrm{I}_{3}\right)$, while the lowest value $\left(3.355 \mathrm{~kg} / \mathrm{m}^{3}\right)$, were obtained under treatment $80 \%$ of AW $\left(\mathrm{I}_{1}\right)$. These result indicate that increasing irrigation intervals from $\left(I_{1}\right)$ up to $\left(I_{3}\right)$ increased the PIW of tuber yield. The higher values of PIW of $\left(I_{3}\right)$ than that of $\left(I_{1}\right)$ is obviously due to the less amount of the water applied (Wa) under treatment $\left(I_{3}\right)$, as shown in Table (7).

\section{Conclusion}

Potatoes are sensitive to water stress thus irrigation has become an essential component of potatoes production in comparison with other crops. Potassium is the nutrient taken up by potatoes in greatest quantity; Therefore, based on water use efficiency values, it is recommended that potato cv. Diamante should be fertilized within $\left(120 \mathrm{~K}_{2} \mathrm{O} \mathrm{kg} / \mathrm{fed}\right.$.) with irrigation of $80 \%$ of available water to achieve the optimum quantity of tuber yield and water productivity.

\section{REFERENCES}

Ali, M.A. (1993) Physiological studies on water requirements of potato plant.. Ph. D. Thesis.Fac. Agric Moshtohor, Zagazig Univ..

Ali. M.H., M. R. Hoque., A. A. Hassan and A.Khair (2007). Effects of deficit irrigation on yield, water productivity and economic returns of wheat. Agric. Water manage., 92: 151-

Balanger, G.; Walsh, J.R.; Richard, J.E.; Milburn, P.H. and Ziadi, N. (2000). Yield response of two potato cultivars to supplemental irrigation on $\mathrm{N}$ fertilization in New Brunswick. American Journal of Potato Research $77(1), 11-21$.

Bosnjak, D;. Pejic, B.and Chartzaulakis, K.S. (1997) Potato water requirement in the Chernozem zone of Yugoslavia..Acta Horticuturae No. 449(I), 211- 215.

Burton, W.G., (1984). The potato. Chapman and Hall, London, pp: 319.

El-Gamal, A.M.(1985).Effect of potassium level on potato yield and quality .J.Agric. Sci. Mansoura Unv.10:1473-1476.

FAO. (1988). An interim report on the state of forest resources in the developing countries. Rome.

FAO.FAOSTAT.Agriculture.Rome,(2004).Availableinhttp://faostat.fao.org/faostat/collections?subset=agriculture. Accessed at:June, 2004.

Fatthallah, M.A. and Ragaa A. Gawish, (1997). Effect of taro intercroping with some vegetable crops on growth, yield and land productivity in relation to several soil moisture regimes. Minufiya J. Agric. Res., 22(6):16471675. 
Gendy,A.A.S.;I,E,Nasr El-Din and A.S. Anter. (2009) Effect of irrigation, potassium application and distance from drain line on wheat crop in clay soil. J.Agric.Res. Kafer-El-Shikh Univ.,35(3)2009.

Ghosh, S.C.; Asanuma, K. K. A., and Toyota, M. (2000). Effects of moisture stress at different growth stages on the amount of total nonstructural carbohydrate, nitrate reductase activity and yield of potato. Japanese Journal of Tropical Agric., 44: $158-166$.

Gomez, K.A. and A.A. Gomez (1984). Statistical procedures for agricultural research. Johns Willey and Sons. Inc. New York, USA.

Hansen, V.W.; D.W. Israelsen and D.E. Stringharm (1979). Irrigation Principle and Practices, $4^{\text {th }}$ ed. Johns Wiley \& Sons., New York.

Humadi, F. M. (1986) Influence of potassium rates on growth and yield of potato. Iraq J. of Agric.Sci.,"Zanco", 4(2), 69-75. (C.f. Field Crop Abst) .39: 7837.

Michael, A.M. (1978). Irrigation theory and particle. Vikas Publishing House PVTLTD New Delhi Bombay.

Ramadan,S. A.;A.A.S. Gendy; A. S. Anter and A.A. El-Leithi (2006). Effect of distance from drain line on wheat crop under different rates of nitrogen fertilization in clay soil. J.Agric. Sci. Mansoura Univ., 31(4):2583-2591

Tisdale, S.L., Nelson, W.L., and Beaton, J.D. (1985). Soil Fertility and Fertilizers. Macmillan Pub. Co.New York. pp: 249-91. ISBN, : 964-033985-7.

Youssef, Y.A.A.; El-Maziny, M.Y.; Abdalla, S.A.; Meleha, M.E. and Hassan, A.A., (2007). Effect of water stress and potassium fertilization on yield quantity and quality of potato. African Crop Science Conference Proceedings, Vol. 8. pp. 445- 455.

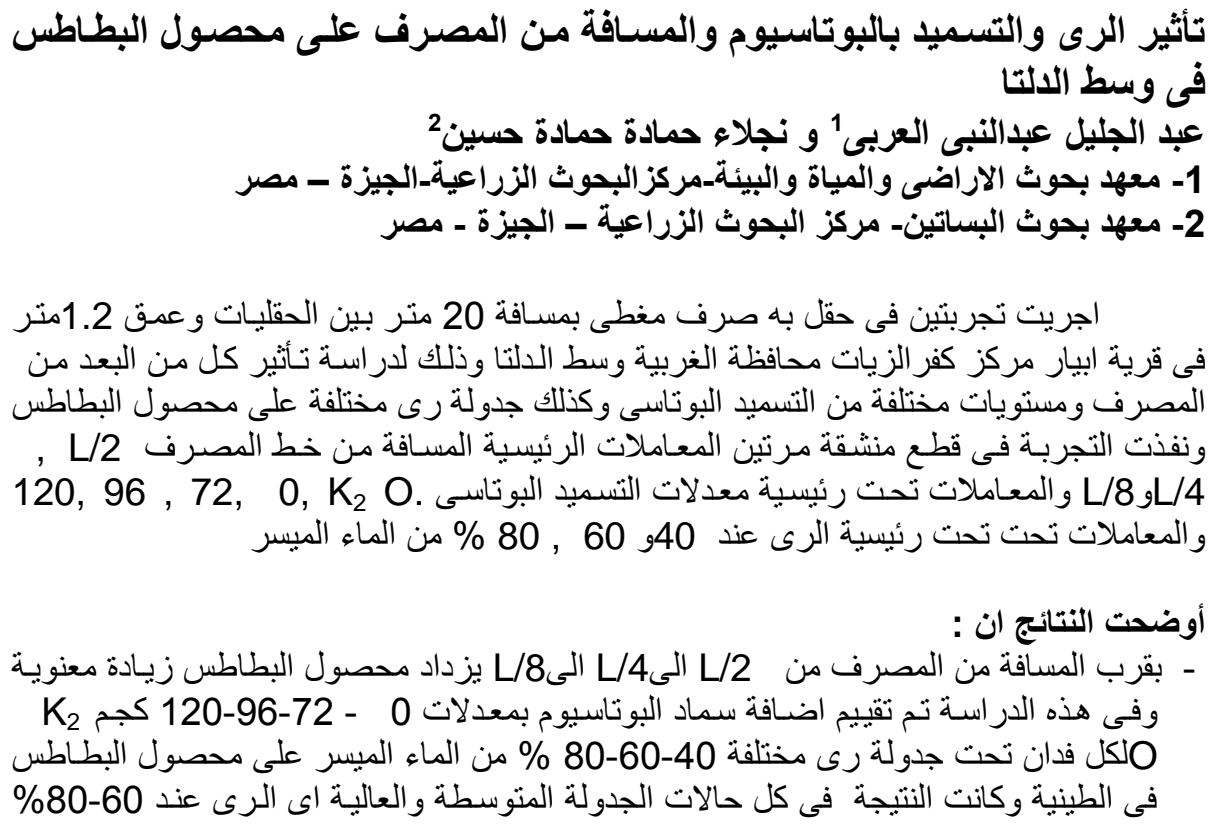




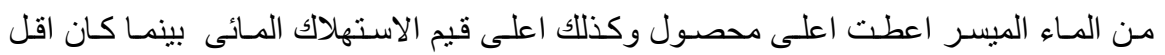

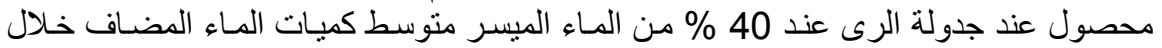

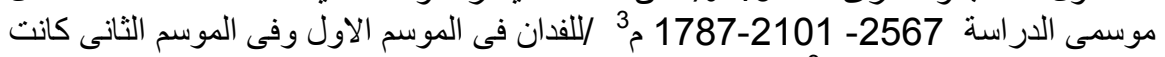

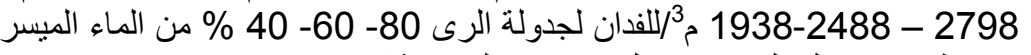

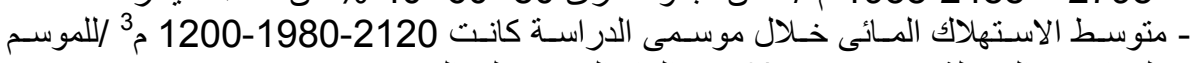

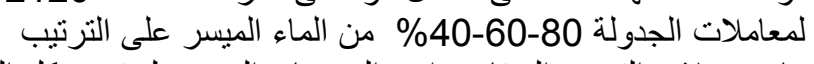

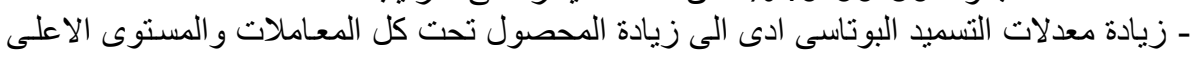

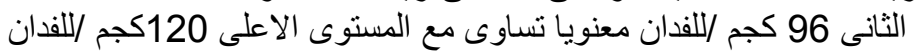

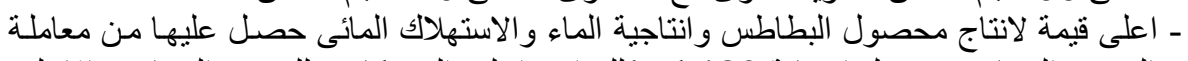

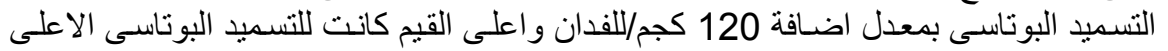

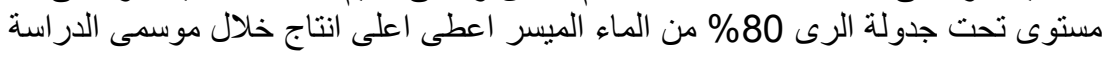

كلية الزراعة - جامعة المنصورة كلية الزراعة - جامعة كفر الثيخ
قام بتحكيم البحث

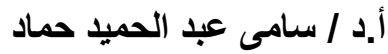

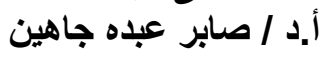

